\title{
A DOR E A GRAÇA: A QUESTÃO DO ANIQUILAMENTO EM PASCAL
}

\author{
Rafael Zambonelli Nogueira* \\ rafael.nogueira@usp.br
}

Resumo: Neste texto, pretendemos analisar de que maneira a questão do aniquilamento se apresenta na filosofia de Blaise Pascal como o dever moral do cristão. Uma vez que a ideia de pecado original ocupa um lugar central nessa filosofia, será a partir da consideração da condição humana decaída e do advento do mediador Jesus Cristo na história, restabelecendo a possibilidade de salvação, que encontraremos os elementos para a compreensão do caráter salvífico que o sacrifício assume no interior da moral pascaliana.

Palavras-chave: Pascal, pecado original, aniquilamento, graça, Jesus Cristo.

"O paradoxo do cristianismo e do catolicismo, diz Merleau-Ponty, é que eles não se detêm jamais seja no Deus interior, seja no Deus exterior, e que eles estão sempre entre um e o outro. Trata-se de ultrapassar-se, é preciso 'perder sua vida', mas, perdendo-a, salvamo-la" (Merleau-Ponty 5, p. 214). Esse paradoxo, nós o vemos assumido em toda a sua radicalidade através da obra de Blaise Pascal. "A conversão verdadeira, diz Pascal, consiste em aniquilar-se diante desse ser universal que tantas vezes tem sido irritado e que pode perder-vos legitimamente a todo momento" (Pascal 8, fr. 470, p. 157) e a felicidade "não está em nós nem fora de nós; está em Deus, e fora e dentro de nós" (Pascal 8, fr. 465, p. 157). O paradoxo, no entanto, não é arbitrário: ele é essencial ao cristianismo e, na visão pascaliana, é justamente o que faz do cristianismo a única religião verdadeira, uma vez que somente ele pode dar conta da realidade paradoxal do homem. Desde então, para que possamos compreender a ideia de aniquilamento na filosofia de Pascal, será necessário recolocá-la no interior desse paradoxo. É a partir dele que se poderá compreender a moral cristã como uma moral do sacrifício.

É no campo das ciências que podemos entrever a primeira figura de nossa condição paradoxal: a ordem da geometria - nossa ciência mais perfeita — consiste "em se manter nesse meio de não definir as coisas claras e entendidas por todos os homens e de definir todas as outras" (Pascal 7, p. 350, grifo nosso). Mas por que deve

*Graduando no departamento de filosofia da USP. 
ser assim? Pascal fala de um "verdadeiro método", aquele de uma ciência ideal, que consistiria em tudo definir e em tudo provar, sem deixar margem para qualquer falta de fundamentação e nos oferecendo, então, um conhecimento perfeito. Ora, é evidente que essa ciência ideal nos é absolutamente inacessível: se tentássemos definir os termos primitivos, precisaríamos de outros termos mais evidentes que lhes servissem de base para a definição; da mesma forma, os novos termos introduzidos precisariam, eles também, de uma definição - e, assim, a tentativa de realizar a ciência ideal redundaria em uma grosseira regressão ao infinito, de sorte que jamais atingiríamos de fato os primeiros termos. Dada essa incapacidade, o que faz, então, a geometria? Ela se contenta em assumir como termos primitivos, quer dizer, como termos não suscetíveis de uma definição, aqueles que nos são imediatamente evidentes para, a partir deles, definir e demonstrar todas as outras coisas. No entanto, é preciso notar que a "luz natural" que nos garante sua extrema evidência - e que será chamada posteriormente de "coração" - apenas diz respeito a um "consenso linguístico" (Chevalley 2, p. 35) 1: por exemplo, todos compreendem a palavra "tempo" na medida em que todos se referem ao mesmo objeto ao ouvi-la ou pronunciá-la, o que não significa, bem entendido, que todos conheçam a essência do tempo: "não é a natureza dessas coisas que eu digo ser conhecida por todos: é apenas e simplesmente a relação entre o nome e a coisa" (Pascal 7, p. 350). As definições, para Pascal, são apenas nominais, ao passo que as definições reais são proposições que devem ser demonstradas para que sua validade seja atestada: se digo que o tempo é o movimento de uma coisa criada e que, doravante, sempre que eu disser "tempo" deve-se entender exclusivamente "o movimento de uma coisa criada”, tenho toda a liberdade de fazê-lo, já que as definições nominais são livres, e não posso ser contradito; se, contudo, mantenho ao mesmo tempo sob a definição "o movimento de uma coisa criada" o sentido ordinário da palavra "tempo", então há possibilidade de refutação e sou obrigado a provar que a natureza do tempo consiste em ser o movimento de uma coisa criada.

Revela-se aqui, portanto, uma limitação do conhecimento humano, visto não podermos atingir os primeiros princípios, o que não impede, todavia, o estabelecimento de uma ciência certa e rigorosa. Pois, embora não seja possível uma ciência perfeita, podemos notar certas propriedades comuns a todas as coisas, já que elas manifestam uma ligação recíproca: "pois não se pode imaginar movimento sem alguma coisa que se mova; essa coisa sendo uma, essa unidade é a origem de todos os números; enfim, o movimento não podendo ser sem espaço, vê-se essas três coisas encerradas na primeira" 
(Pascal 7, p. 351) e também o tempo é relativo ao movimento, manifestando uma relação necessária e recíproca entre as grandezas fundamentais. A principal propriedade comum, diz Pascal, é a dupla infinitude: "qualquer movimento, qualquer número, qualquer espaço, qualquer tempo que seja, há sempre um maior e um menor: de sorte que eles se sustentam todos entre o nada e o infinito, estando sempre infinitamente distantes desses extremos" (Pascal 7, p. 352). Seja um número qualquer. Pode-se sempre conceber um que seja maior e assim ao infinito, sem que se chegue jamais a um número que não possa ser aumentado; simetricamente, por menor que seja um número, pode-se sempre conceber um menor, ao infinito, sem que se chegue ao zero. E, não obstante sua extrema evidência, há aqueles que negam a divisibilidade ao infinito das grandezas, afirmando, por exemplo, que o espaço é composto por indivisíveis. É assim, dizem eles, porque um conteúdo divisível ao infinito é inconcebível...

É uma doença natural ao homem, afirma Pascal, crer que possui a verdade diretamente; e por isso ele está sempre disposto a negar tudo o que lhe é incompreensível; ao passo que, com efeito, ele não conhece naturalmente senão a mentira e que ele não deve tomar por verdadeiras senão as coisas cujo contrário lhe parece falso (Pascal 7, p. 352)

O que está em questão aqui é a recusa pascaliana de uma evidência direta da verdade, tal como uma ideia clara e distinta cartesiana: afirma-se a divisibilidade ao infinito não porque se a compreenda claramente, mas porque seu contrário é absurdo. De fato, como conceber que dois indivisíveis se tocam? Se eles se tocam inteiramente, eles são uma e a mesma coisa — de sorte que infinitos indivisíveis não formam senão um único indivisível, e jamais uma extensão -; se se tocam em uma parte, resta que eles possuem partes e não são portanto indivisíveis. O defensor dessa tese poderia ainda tentar uma última cartada: assim como duas unidades, que não são números, formam um número, dois indivisíveis, que não são extensos, podem formar uma extensão. Ora, dirá Pascal, os indivisíveis não são do mesmo gênero que as grandezas: ocorreu a Euclides, por necessidade do discurso, dizer que a unidade não é um número; todavia, ela é do mesmo gênero que o número e, portanto, tem proporção com ele - lembremos que as definições são meramente nominais, elas não nos dão a essência da coisa. Deverse-ia comparar o indivisível ao zero: assim como dois zeros não formam um número, dois indivisíveis não podem formar uma extensão. A tese dos indivisíveis é, enfim, 
absurda, o que nos obriga a admitir a tese contrária, malgrado sua incompreensibilidade para nós.

A importância dessa análise para nós vem do fato de que "o infinito potencial implicado por essas grandezas indica que elas flutuam entre o infinito e o nada reais" (Oliva 6, p. 52). Há uma distância qualitativa intransponível entre o finito e o infinito que proíbe qualquer salto de um ao outro: o finito não tem proporção com o infinito. Não por acaso Pascal termina o opúsculo Do Espírito Geométrico com uma consideração sobre a condição humana:

Mas aqueles que virem claramente essas verdades poderão admirar a grandeza e a potência da natureza nessa dupla infinitude que nos circunda de todas as partes e aprender por essa consideração maravilhosa a se conhecer, olhando-se colocados entre uma infinitude e um nada de extensão, entre uma infinitude e um nada de número, entre uma infinitude e um nada de movimento, entre uma infinitude e um nada de tempo. Através disso pode-se aprender a estimar-se em seu justo valor e formar reflexões que valem mais que todo o resto da geometria (Pascal 7, pp. 354-5).

Nos Pensamentos essa dupla infinitude terá uma função apologética capital — a consideração da infinitude potencial das grandezas nos torna sensíveis à nossa finitude e incapacidade, na medida em que ela própria nos ultrapassa, e, ao mesmo tempo, nos aproxima moralmente do infinito real. É a desproporção do homem, título do fragmento 72, que se manifestará em meio a essa consideração.

Analisemos, pois, esse fragmento. Pascal nos propõe aqui um "exercício de pensamento", que tem por objetivo fazer com que o homem se dê conta de sua condição de meio:

Afinal, que é o homem dentro da natureza? Nada em relação ao infinito; tudo em relação ao nada; um ponto intermediário entre tudo e nada. Infinitamente incapaz de compreender os extremos, tanto o fim das coisas como o seu princípio permanecem ocultos num segredo impenetrável, e é-lhe igualmente impossível ver o nada de onde saiu e o infinito que o envolve (Pascal 8, fr. 72, p. 56).

Ao considerar a natureza, o homem percebe-se envolvido por uma dupla infinitude que 
o ultrapassa: por um lado, o homem se vê como um nada diante da magnitude da natureza que ultrapassa todas as suas capacidades — "todo esse mundo visível é apenas um traço imperceptível na amplidão da natureza, que nem sequer nos é dado conhecer mesmo de um modo vago" (Pascal 8, fr. 72, p. 55) —; por outro lado e simetricamente, ao considerar a natureza em sua pequenez, o homem vê suas capacidades ultrapassadas também pelo infinitamente pequeno - lembremos da divisibilidade infinita - e aparece como "um colosso, um mundo, ou melhor, um todo em relação ao nada a que não se pode chegar" (Pascal 8, fr. 72, p. 56). Haverá aqui um jogo, como o nota Oliva (Oliva 6, pp. 60-1), entre um infinito e um indivisível aparentes e o infinito e o indivisível reais, que atinge profundamente a pretensão humana de conhecimento: há uma desproporção de fato entre o homem e a natureza, relativa à nossa capacidade finita, que dissimula para nós a desproporção de direito do homem com o infinito real — nós "consideramos últimos os que parecem últimos à nossa razão, tal qual fazemos com as coisas materiais, em que denominamos ponto indivisível aquele para além do qual nossos sentidos nada mais distinguem, embora continue divisível independentemente por sua própria natureza" (Pascal 8, fr. 72, p. 57). Em outras palavras, a dupla infinitude da natureza - ela mesma envolvida pela dupla infinitude real - já basta para que tenhamos consciência de nossa incapacidade de abarcá-la:

Ardemos no desejo de encontrar uma plataforma firme e uma base última e permanente para sobre ela edificar uma torre que se erga até o infinito; porém, os alicerces ruem e a terra se abre até o abismo. Não procuremos, pois, segurança e firmeza. Nossa razão é sempre iludida pela inconstância das aparências e nada pode fixar o finito entre os dois infinitos que o cercam e dele se afastam (Pascal 8, fr. 72, p. 58).

Desde então, é a própria possibilidade de um conhecimento certo que se acha comprometida, dada nossa condição de meio. No entanto, não seria possível que o homem conhecesse os objetos que lhe estão mais próximos e que têm com ele proporção? Pascal responderá pela negativa: "as partes do mundo, diz ele, têm todas tais relações e tal encadeamento umas com as outras que considero impossível compreender uma sem alcançar as outras, e sem penetrar o todo" (Pascal 8, fr. 72, p. 59). Todas as coisas, participando da dupla infinitude, nos escapam: "uma coisa depende da outra, e uma conduz à outra. Esses extremos se tocam e se unem, à força de se afastarem, e se 
reencontrarem em Deus e somente em Deus" (Pascal 8, fr. 72, p. 57). Assim, é a presunção de conhecimento dos filósofos que cai por terra: a realidade das coisas é "uma esfera infinita cujo centro se encontra em toda parte e cuja circunferência não se acha em nenhuma" (Pascal 8, fr. 72, p. 55) - quer dizer, se tentamos abraçar sua circunferência, fracassamos por ela ultrapassar infinitamente nossas capacidades; se, ao contrário, tentamos alcançar seu centro (encontrar os ditos “princípios”), fracassamos igualmente. A chave para isso está na palavra meio que define nossa condição. É-nos impossível deixar o meio, pois a distância em relação a qualquer um dos dois extremos é infinita e seria necessário, para atingir um conhecimento efetivo da realidade, juntar os dois extremos, mas "a natureza pôs-nos de tal modo no meio que, se trocamos um lado da balança, trocamos também o outro" (Pascal 8, fr. 70, p. 54), quer dizer, se nos dirigimos a um dos infinitos, somos lançados em direção ao outro (por exemplo, se nos aproximamos do nada, vemo-nos como um todo e vice-versa) e, assim, permanecemos no meio, infinitamente distantes de um e outro. Há ainda algo que agrava nossa incapacidade epistêmica: não só, por nossa condição, só conhecemos as aparências flutuantes das coisas, como somos também incapazes de conhecê-las por serem simples em si, enquanto somos compostos por duas naturezas antagônicas, a alma e o corpo. "Em vez de recebermos a idéia pura das coisas, diz Pascal, tingimo-la com nossas qualidades e impregnamos de ser composto todas as coisas simples que contemplamos", de modo que não só não podemos conhecer o corpo isoladamente e a alma isoladamente, mas também somos absolutamente incapazes de conhecer sua união: "essa é a sua dificuldade máxima e, não obstante, a sua própria essência" (Pascal 8, fr. 72 , p. 60).

Para compreender o real alcance dessa análise, é importante notar como se inicia o fragmento: "eis aonde nos conduzem os conhecimentos naturais. Se estes não são verdadeiros, não há verdade no homem; e, se o são, ele descobre nisso um grande motivo de humilhação" (Pascal 8, fr. 72, p. 55). O que está em questão aqui é, portanto, a humilhação do homem a partir de sua pretensão ao conhecimento: mostrando nossa incapacidade de conhecer o infinito, a natureza e nossa própria essência — podemos conhecer apenas nossa situação mediana - Pascal revela a baixeza de nossa condição e a fragilidade de nossa razão. Doravante, o homem não pode mais se voltar aos objetos para conhecê-los, nem mesmo a si próprio, pois tudo lhe escapa e essa relação impossível dará lugar a uma espécie de sentimento de pavor e admiração diante do infinito, que é como uma "contemplação silenciosa" que consiste em conhecer que nada 
se pode conhecer. "É horrível sentir escoar tudo o que se possui” (Pascal 8, fr. 212, p. 96). É esse conhecimento, essa contemplação silenciosa que faz com que nosso ser paradoxal irrompa:

Qualquer objeto a que pensemos apegar-nos e consolidar-nos abandona-nos e, se o perseguimos, foge à perseguição. Escorrega-nos entre as mãos numa eterna fuga. Nada se detém por nós. É o estado que nos é natural e, no entanto, nenhum será mais contrário à nossa inclinação (Pascal 8, fr. 72, p. 58, grifo nosso).

O homem se descobre, portanto, como um "monstro incompreensível", a razão é humilhada e descobre sua impotência no momento mesmo em que se pensava grande: o homem não pode conhecer-se a si próprio, pois o caráter paradoxal irrecusável de sua condição furta-se ao discurso da razão. Avessa à contradição, movendo-se apenas em meio à univocidade translúcida das demonstrações geométricas, a razão deve submeterse àquilo que a ultrapassa infinitamente. "A última tentativa da razão, assevera Pascal, é reconhecer que há uma infinidade de coisas que a ultrapassam. Revelar-se-á fraca se não chegar a percebê-lo" - e não poderia ser diferente, pois "se as coisas naturais a ultrapassam, que dizer das sobrenaturais?" (Pascal 8, fr. 267, p. 110).

O que dizer, porém, dessa "humilhação" da razão? Não nos enganemos: a reflexão pascaliana não se detém na constatação da impotência da razão, como se discurso algum fosse possível. Pascal não é o Crátilo da modernidade. É verdade que sua insistência nesse tópico pode suscitar tal interpretação, mas não é menos verdade que há diversas passagens que esclarecem seu sentido: não se trata de negar a razão, mas apenas de limitá-la. O objeto da crítica não é a razão propriamente dita, mas a razão "imperialista" que acredita ser capaz de dominar até os mínimos recantos da realidade. A realidade de que fala Pascal é heterogênea, de sorte que uma única ordem de inteligibilidade, uma mathesis universalis como queria Descartes, se torna um contrasenso (Cf. Chavalley 2, pp. 55 e ss.). Em um contexto apologético, a afirmação da heterogeneidade é de importância capital. Se Descartes podia sem quaisquer problemas estabelecer provas racionais da existência de Deus, é essa possibilidade que é posta em questão por Pascal. Descartes é "inútil e incerto" (Pascal 8, fr. 78, p. 62) e, a bem da verdade, sua inutilidade supera sua incerteza. Por quê? Em primeiro lugar, devido à desproporção do homem que o fragmento 72 já desnudou: “se há um Deus, ele é 
infinitamente incompreensível, pois, não tendo partes nem limites, não tem nenhuma relação conosco. Somos, portanto, incapazes de conhecer não só o que ele é como também se existe" (Pascal 8, fr. 233, p. 99). Em segundo lugar, porque, mesmo se nossa razão fosse capaz de conhecer sua existência e sua natureza, com todas as provas já produzidas a respeito há, contudo, aqueles que não acreditam em Deus.

As provas metafísicas de Deus acham-se tão afastadas do raciocínio dos homens e tão embrulhadas que pesam pouco; e, mesmo que isso servisse para alguns, serviria apenas durante o instante em que vissem essa demonstração; mas, uma hora depois, receariam ter-se enganado (Pascal 8, fr. 543, p. 169).

Desde então, será preciso encontrar uma nova maneira de se fazer uma apologia que não passe pelos instrumentos inúteis da metafísica. Retomemos, pois, a análise pascaliana da condição humana para que se manifeste, a partir daí, sua estratégia apologética: ela deverá empreender a tarefa de recusar as provas racionais de Deus e, ao mesmo tempo, mostrar ao libertino que a posição cristã é a mais razoável.

\section{II}

Se as limitações explicitadas no âmbito do conhecimento, revelando-nos a desproporção, já nos levaram a encontrar no homem uma situação paradoxal (de um estado que nos é natural e, no entanto, é o mais contrário à nossa inclinação), veremos que podemos reencontrá-la em diversos âmbitos, como, por exemplo, naquilo que Pascal chama de "divertimento". Por que os homens se lançam incessantemente às mais diversas atividades? Sabe-se bem que a verdadeira felicidade consiste no repouso... Então, conclui-se que a infelicidade dos homens deve-se ao fato de que eles não sabem simplesmente ficar quietos dentro de um quarto (Cf. Pascal 8, fr. 139, p. 75). No entanto, diz Pascal, "nada é mais insuportável ao homem do que um repouso total, sem paixões, sem negócios, sem distrações, sem atividade. Sente então seu nada, seu abandono, sua insuficiência, sua dependência, sua impotência, seu vazio" (Pascal 8, fr. 131, p. 74). Portanto, é preciso reconhecer que os homens devem buscar a agitação para não ter de encarar a infelicidade natural de sua condição fraca e miserável, pois "nossa natureza está no movimento; o inteiro repouso é a morte" (Pascal 8, fr. 129, p. 74). Todavia, prossegue Pascal, embora os homens devam procurar o divertimento, não há 
efetivamente felicidade nisso e a verdadeira beatitude não consiste "em se ter o dinheiro que se pode ganhar no jogo, ou na lebre que se persegue: nada disso nos interessaria se nos fosse oferecido" (Pascal 8, fr. 139, p. 75). Compreendamos: não é a lebre que nos desvia da visão de nossa miséria, mas a caça, ou seja, o erro não consiste em procurar o divertimento, mas em imaginar que a posse daquilo que se busca seja a felicidade, o repouso. Como diz Lebrun,

A atividade dos homens é ordenada em função de uma dupla finalidade: a finalidade sem fim e a finalidade interessada. A emoção do jogo e o chamariz do ganho? Não. Este segundo fim é uma ilusão.... Não há neste mundo finis ultimis nem summum bonum, como o pretendiam os moralistas antigos. Os homens acreditam que buscam o repouso, e um repouso definitivo, depois do esforço. Mas eles se enganam (Lebrun 4, p. 18).

Não obstante eles se enganem em relação a isso, há algo de certo em seu erro: de fato, a felicidade consiste verdadeiramente no repouso, ainda que, em nossa condição, ele nos seja insuportável e nós não busquemos senão a atividade — os homens, diz Pascal, "têm um instinto secreto, que os leva a procurar divertimentos e ocupações exteriores, nascido do ressentimento de suas contínuas misérias; e têm outro instinto secreto, resto da grandeza de nossa primeira natureza, que os faz conhecer que a felicidade só está, de fato, no repouso, e não no tumulto" (Pascal 8, fr. 139, p. 77).

Ora, há um método, muito mais sutil que o da geometria, que vai se desenhando nessas linhas: é a reviravolta do pró ao contra que nos leva à razão dos efeitos (“depois de haver encontrado a causa de todas as nossas infelicidades, quis descobrir-lhes a razão", Pascal 8, fr. 139, p. 75). Isso significa que, para os diferentes efeitos contraditórios, é possível encontrar uma razão que dê conta da verdade parcial e do erro parcial de cada um, pois "todos erram tanto mais perigosamente quanto cada qual busca uma verdade. Seu erro não consiste em seguir uma falsidade, mas em não seguir outra verdade" (Pascal 8, fr. 863, p. 270). A verdade assumirá, portanto, um caráter paradoxal na filosofia de Pascal, de sorte que ela não poderia jamais ser encontrada pelo geômetra - seu terreno é o da finura, na qual os princípios são ainda sentidos com clareza, mas, dada sua sutileza, eles não se deixam manejar de maneira tão simples como na geometria (cf. Pascal 8, fr. 1, p. 41). Para que esse método se explicite, analisemos um outro fragmento: 
Razão dos efeitos - Graduação. O povo honra as pessoas de grande nascimento. Os semi-hábeis as desprezam, dizendo que o nascimento não é uma vantagem da pessoa, mas do acaso. Os hábeis as honram, não pelo pensamento do povo, mas pelo pensamento oculto. Os devotos, que têm mais zelo do que ciência, as desprezam, malgrado essa consideração que as faz honrar pelos hábeis, porque julgam isso por uma nova luz que a piedade lhes dá. Mas os cristãos perfeitos as honram por outra luz superior. Assim, vão-se sucedendo as opiniões do pró ao contra, segundo a luz que se tem (Pascal 8, fr. 337, p. 124).

Neste fragmento, temos cinco posições que acabam por se reduzir a duas proposições contraditórias: é preciso honrar as pessoas de grande nascimento; não se deve honrar as pessoas de grande nascimento. No entanto, há certa ordem de sucessão das opiniões que é indicada no começo pela palavra gradação — os hábeis têm a mesma opinião que o povo, mas não pelo pensamento do povo, assim como os cristãos perfeitos, que julgam por uma luz superior, compartilham da mesma opinião que o povo e os hábeis, mas segundo motivos diferentes; da mesma forma, identificam-se as opiniões dos semihábeis e dos devotos, mas estes estão um passo além daqueles por uma nova luz que a piedade lhes dá. Na reviravolta do pró ao contra, encontramos as mesmas posições matizadas por diferentes graus de conhecimento. O povo acha que se deve honrar as pessoas de grande nascimento porque acredita que o berço seja uma vantagem efetiva; os semi-hábeis, contra o povo, têm razão em afirmar que o nascimento é um mero acaso; os hábeis, por sua vez, sabem que o nascimento não é uma vantagem efetiva, mas também sabem que, não havendo qualquer fundamento real para o poder, é preciso respeitar as grandezas estabelecidas para que a ordem social se mantenha (cf. Pascal 8, frs. 312, 313, 319, 325); os devotos, pela luz que a piedade lhes dá, criticam os hábeis porque, embora seja verdade que a obediência do povo garante a ordem social, não é menos verdade que todos os homens são iguais diante de Deus (Lebrun 4, p. 25) e, portanto, o povo não deve honrar os de grande nascimento; ao passo que os cristãos perfeitos, tendo uma luz superior, defendem a opinião do povo, visto que é inútil buscar a realização do absoluto neste mundo, pois eles compreendem a verdade parcial que existe em cada uma das posições anteriores, quer dizer, conhecem a razão que coordena os diferentes efeitos contraditórios - esta razão será, com efeito, a condição decaída do homem após o pecado original, que faz com que ele tenha duas naturezas distintas, quer 
dizer, uma natureza de grandeza que é um vestígio de seu estado original pré-adâmico e uma natureza de miséria que é seu estado corrompido após o pecado. É essa contradição essencial do homem que faz sua condição trágica: há uma exigência de absoluto que é irrealizável neste mundo, o homem não pode nem escolher apenas um elemento do paradoxo nem aceitá-lo, mas é obrigado a vivê-lo (Goldmann 3, pp. 244-5). Há, portanto, uma verdade paradoxal de nossa condição que apenas a religião pode nos revelar.

No contexto que nos interessa aqui, o da moral, poderemos observar esse mesmo movimento na oposição entre os pirrônicos e os dogmáticos ou — em seus maiores expoentes segundo a leitura pascaliana da história da filosofia — na oposição entre Montaigne e Epiteto. É curioso notar como isso aparece antes mesmo dos Pensamentos, na Entrevista com M. de Saci de 1655, e já com o objetivo de mostrar a utilidade dos dois autores para a religião. "Epiteto, diz Pascal, é um dos filósofos do mundo que melhor conheceu os deveres do homem" (Pascal 7, p. 292). Para ele, o homem deveria ter Deus como seu principal objeto, submeter-se inteiramente à Sua vontade, o que equivale a dizer que se deve acima de tudo conhecer Deus e amá-lo. Por outro lado, Montaigne, fazendo com que tudo se mantenha em suspenso em uma dúvida universal que duvida inclusive de si mesma — não se pode nem mesmo dizer "eu não sei”, mas, ao contrário, “que sei eu?" —, mostra a impotência da razão em conseguir fixar, por si própria, o que quer que seja, de sorte que o homem apenas pode ter acesso às aparências flutuantes e oscilantes das coisas, sem jamais alcançar um ponto fixo em que assentar sua crença. Temos, portanto, duas posições opostas: Epiteto, conhecendo os deveres do homem, ressalta sua grandeza, na medida em que sua finalidade é Deus; Montaigne, conhecendo a impotência da razão, ressalta sua miséria, na medida em que faz a razão descer da excelência que se atribuía, colocando o homem em paralelo com as bestas. Malgrado os elogios de Pascal a esses dois filósofos, é preciso lembrar que, em regime de queda, todo Dr. Jekyll traz consigo um Mr. Hyde: Epiteto, conhecendo a grandeza do homem através de seus deveres, ignora sua impotência, perdendo-se, assim, na presunção - ele confunde aquilo que se deve com aquilo que se pode, chegando à "soberba diabólica" de afirmar que o homem é perfeitamente capaz de, por suas próprias forças, conhecer a divindade, obedecê-la, adquirir todas as virtudes, ao ponto de pensar que a alma do homem é uma porção da substância divina (Pascal 7, p. 293); Montaigne, por sua vez, conhecendo a impotência, mas não a grandeza de seus deveres, acaba por se acomodar no laxismo — o verdadeiro e o bem são tão pouco sólidos que 
não se deve forçá-los, mas apenas tomá-los em sua primeira aparência, tendo portanto como regra de ação a comodidade e a tranquilidade (Pascal 7, p. 296).

Seríamos, então, tentados a uma conciliação entre os dois opostos com vistas a uma moral perfeita. Ledo engano, dirá Pascal: de sua reunião resultaria apenas uma guerra e uma destruição geral, pois "um estabelecendo a certeza, o outro a dúvida, um a grandeza do homem, o outro sua fraqueza, eles destroem tanto a verdade quanto a falsidade um do outro" (Pascal 7, p. 296). Destruindo-se mutuamente, as duas posições dão lugar à verdade do Evangelho — não se trata portanto de conciliar, mas de buscar a razão dos efeitos, aquilo que origina o paradoxo. Epiteto e Montaigne não são conciliáveis porque remetem tanto a grandeza quanto a miséria à mesma coisa, a saber, à natureza; ao passo que a fé nos ensina a remetê-las a coisas diferentes: o que há de grandeza à graça, o que há de miséria à natureza. É mais uma vez a dupla natureza do homem, no interior de uma doutrina da queda, que reaparece como a razão que pode harmonizar as contradições (o que não significa, com efeito, dissipá-las): "a natureza do homem considera-se de duas maneiras: uma segundo seu fim, e, então, ele é grande e incomparável; outra segundo a multidão, como se julga a natureza do cavalo e do cão, ao ver sua corrida e seu animum arcendi; e, então, o homem é abjeto e vil"' (Pascal 8, fr. 415, pp. 138-9). É por isso, então, que Pascal pode afirmar que o pirronismo e o dogmatismo estão em uma guerra na qual todos devem, necessariamente, tomar partido: visto que cada um constitui um ponto de vista unilateral da realidade do homem, é preciso escolher um dos dois opostos, pois "quem pensar em permanecer neutro será pirrônico por excelência" (Pascal 8, fr. 434, p. 148). E, ao mesmo tempo em que não se pode evitar um desses dois partidos, também não se pode subsistir em nenhum, dada sua unilateralidade. "A natureza confunde os pirrônicos, e a razão confunde os dogmáticos", quer dizer: é impossível subsistir no pirronismo porque é a própria natureza que impede um pirronismo consequente — não obstante seu discurso de dúvida absoluta, a natureza não permite que ele extravague ao ponto de levar essa dúvida às últimas consequências, pois, embora seja impossível saber se o pão que está diante de mim me alimentará como o pão que comi ontem, Hume não morreu de fome, uma vez que havia nele uma certeza que não era da ordem da razão discursiva -; não se pode subsistir no dogmatismo porque os céticos, levando a razão ao seu limite e mostrando a impossibilidade do conhecimento dos princípios, obrigam os dogmáticos, que tanto se ufanam da potência da razão, a se refugiarem no irracional, num sentimento natural ou instinto. "Quem não vê, por tudo isso, que o homem está extraviado, que caiu do seu lugar, que o procura 
com inquietude, que não pode mais tornar a encontrá-lo? E quem, então, o conduzirá para aí? Os maiores homens não o conseguiram” (Pascal 8, fr. 431, p. 146).

Precisemos, pois, essa duplicidade encontrada na natureza do homem:

Todos os homens, diz Pascal, procuram ser felizes; não há exceção. (...) A vontade nunca efetua a menor diligência, senão com esse objetivo. Esse é o motivo de todas as ações de todos os homens, até mesmo dos que vão enforcar-se. E, no entanto, depois de tão grande número de anos, nunca ninguém, sem a fé, chegou a esse ponto a que todos visam continuamente (Pascal 8, fr. 425, p. 141).

Aqui, como em qualquer lugar, vemos que há no homem uma exigência de absoluto o verdadeiro bem, o repouso, a verdade, a justiça etc. — que é vivida como irrealizável. É isso que define, como vimos, a tragicidade de sua condição:

Que nos gritam, pois, essa avidez e essa impotência se não que houve, outrora, no homem, uma verdadeira felicidade, da qual lhe restam, agora, a marca e o traço vazio, que ele tenta inutilmente encher de tudo o que o rodeia, procurando nas coisas ausentes o socorro que não obtém das presentes, embora aquelas sejam incapazes de socorrê-lo, porque esse abismo infinito só pode ser preenchido por um objeto infinito e imutável, isto é, pelo próprio Deus? (Pascal 8, fr. 425, p. 141).

Todas as contradições que encontramos no homem remetem, em última análise, à queda. Afinal, dada a exigência de absoluto presente nele, é preciso reconhecer, por um lado, que ele tenha caído de um estado no qual gozava, em sua inocência, da verdade e da felicidade; e, por outro lado, que ele tenha a reminiscência de seu estado original, quer dizer, um princípio de grandeza sem o qual ele nem mesmo teria a ideia da verdade ou da beatitude (cf. Pascal 8, fr. 434, p. 149). Assim, o homem busca a verdade e só encontra incertezas; busca a felicidade e só encontra miséria e morte — "somos incapazes de não desejar a verdade e a felicidade e somos incapazes da certeza ou da felicidade. Deixam-nos este desejo tanto para nos punir como para nos fazer sentir de 
onde caímos" (Pascal 8, fr. 437, p. 151).

Para evitar equívocos na interpretação dessa duplicidade da natureza do homem, retomemos, antes de avançar em nossa análise, a questão da heterogeneidade da realidade para Pascal. "A distância infinita dos corpos aos espíritos figura a distância infinitamente mais infinita dos espíritos à caridade, pois ela é sobrenatural" (Pascal 8, fr. 793, p. 248). Como o lembra Bénichou (Bénichou 1, pp. 112 e ss.), no âmbito propriamente teológico, a afirmação da ruptura absoluta entre as ordens humana e divina em Pascal se contrapõe diretamente ao "cristianismo otimista" da época, notadamente aquele professado por Desmarets, que estabelecia uma ligação entre essas duas ordens por uma gama ascendente e contínua de perfeição. Ora, esse processo de ascensão terrestre só faz sentido na medida em que se admite um vestígio real e ativo no homem de sua grandeza original - é precisamente essa ideia que Pascal pretende esconjurar pela afirmação da heterogeneidade das ordens, pois ela nos levará a conceber a grandeza do homem não como uma grandeza real, como o queria Desmarets, mas como o sentimento de uma falta dolorosa. Daí vem a importância capital de desnudar a impotência da razão: a ordem dos espíritos - que seria aquela intermediária entre a ordem da natureza e a da graça - se manifesta ela também corrompida e, portanto, seria inútil dela exigir uma mediação. A separação é radical: Pascal não nega dogmaticamente a razão, mas, utilizando-se do cético, faz com que ela se negue a si mesma. "A grandeza do homem, diz Pascal, é grande na medida em que ele se conhece miserável” (Pascal 8, fr. 397, p. 136) e ele insistirá em que a miséria se infere da grandeza, e a grandeza da miséria, pois o homem "é miserável, de vez que o é; mas é bem grande, de vez que o sabe" (Pascal 8, fr. 416, p. 139). Reencontramos aqui, mais uma vez, aquela grandeza segundo a finalidade e aquela miséria segundo a impossibilidade de realizá-la ou, em outros termos, a condição trágica que consiste em viver o paradoxo da exigência de um absoluto irrealizável:

Assim, a única grandeza do homem é que ele sente sua miséria; sua natureza não é alta senão porque ela não pode ser baixa com tranquilidade e, quando Pascal afirma a grandeza do homem, é sempre para decidir pela inquietude e pela angústia. Somente o contraste entre os dois termos extremos subsiste e o que pôde restar, no entre-dois, do primeiro estado do homem, longe de abrandar esse contraste, serve apenas, em seu estado atual, para acusá-lo ainda mais (Bénichou 1, pp. 120-1). 
Feitas essas considerações, às quais retornaremos adiante, podemos agora nos perguntar: como compreender essa duplicidade? Pascal insiste em que essas contrariedades podem ser encontradas sem dificuldade nas mais diversas experiências humanas. E, no entanto, os filósofos jamais puderam dar conta realmente de nossa condição, visto agarrarem-se todos a apenas um dos termos da contradição. Mesmo que ela se manifeste a cada momento de nossa vida, foi impossível ao homem compreendêla - ela é vivida e, todavia, não se vê, sem a fé, a sua razão. É aqui que entra em cena o apologista: se há uma religião verdadeira, é preciso, então, que ela seja capaz de nos explicar essas "espantosas contrariedades" e, mais, que ela "nos ensine os remédios para essas impotências e os meios de obter esses remédios" (Pascal 8, fr. 430, pp. 142-3). Que outra religião o fez, pergunta-se Pascal, senão a cristã? Vejamos o que diz a sabedoria de Deus:

\footnotetext{
"Não espereis", diz ela, "nem a verdade nem a consolação dos homens. Eu sou aquela que vos formou e a única que pode ensinar-vos o que sois. Mas não estais, agora, no estado em que vos formei. Criei o homem santo, inocente, perfeito; enchi-o de luz e de inteligência; comuniquei-lhe minha glória e minhas maravilhas. Os olhos do homem viam, então, a majestade de Deus. Não se achava nas trevas que o cegam, nem na mortalidade e nas misérias que o afligem" (Pascal 8, fr. 430, p. 143).
}

Ora, Adão, não obstante a finitude intrínseca à condição de criatura, tinha certa proporção com Deus, que lhe havia sido concedida pelo próprio Deus uma vez que Adão possuía uma graça suficiente (Pascal 7, p. 317): Deus não podia, com justiça, impor os mandamentos a Adão inocente sem lhe dar a graça necessária para observálos. Essa graça não suprime o livre-arbítrio - Adão era livre para perseverar ou não na justiça divina, a qual ele conhecia pela graça concedida. Assim, sua vontade era naturalmente inclinada, e não determinada, ao bem na medida em que Deus era sua finalidade e a medida de todo o bem. No entanto, a sabedoria divina continua seu discurso:

"Mas não pôde manter tanta glória sem cair na presunção. Quis tornar-se o centro de si mesmo, independente do meu socorro. Subtraiu-se ao meu domínio; igualando-se a mim pelo desejo de 
encontrar a sua felicidade em si mesmo, abandonei-o; revoltando as criaturas que lhe estavam submetidas, tornei-as suas inimigas: de maneira que, hoje, o homem tornou-se semelhante aos animais, e num tal afastamento de mim que apenas lhe resta uma luz confusa do seu autor... (...) "Eis o estado em que os homens se acham hoje. Resta-lhes algum instinto impotente de felicidade de sua primeira natureza, e estão mergulhados nas misérias de sua cegueira e de sua concupiscência, a qual se tornou sua segunda natureza" (Pascal 8, fr. 430, pp. 143-4).

Ressaltemos a última sentença: após o pecado, a natureza do homem se reduziu à concupiscência. A concupiscência é, em termos gerais, aquilo que faz com que o homem se volte às criaturas, aos bens terrenos. Tendo perdido a graça suficiente, é preciso notar que o homem perdeu também aquele livre-arbítrio de indiferença de que gozava Adão: este era flexível ao bem e ao mal, mas visto que possuía a graça suficiente, era naturalmente inclinado ao bem; o pecador, por sua vez, se tornou escravo da concupiscência, sua vontade é agora naturalmente determinada ao mal na medida em que deixou de se dirigir a Deus e se voltou para si mesma como ao seu objeto último. Há um falso véu de bem que nos dissimula toda a corrupção de nosso ser dominado pela concupiscência: "basearam-se e extraíram-se da concupiscência regras admiráveis de polícia, moral e justiça; mas no fundo, neste fundo vil do homem, esse figmentum malum apenas se mascara; não desaparece" (Pascal 8, fr. 453, p. 154). Desde então, é preciso reconhecer que toda a realidade humana não é outra coisa senão concupiscência — “'tudo o que há no mundo é concupiscência da carne [volúpia], ou concupiscência dos olhos [curiosidade], ou orgulho da vida: libido sentiendi, libido sciendi, libido dominandi" (Pascal 8, fr. 458, p. 155), que correspondem às três ordens de realidade: os corpos, os espíritos e a vontade ou justiça - e que, portanto, "sendo todos os homens nessa massa corrompida igualmente dignos da morte eterna e da cólera de Deus, Deus podia com justiça abandoná-los todos sem misericórdia à danação” (Pascal 7, p. 318).

Como, no entanto, surge essa concupiscência no homem? Pascal responde a essa pergunta em uma carta à sua irmã, quando da morte de seu pai (Pascal 7, p. 277). Deus, diz ali Pascal, criou o homem com dois amores: um por Deus e outro por si mesmo, sendo o primeiro um amor infinito sem nenhum outro fim senão o próprio Deus e o segundo finito e, por isso mesmo, dirigido a Deus, na medida em que o amor de si em Adão era o amor de si enquanto criatura. Ora, uma vez advindo o pecado, o homem 
perdeu o primeiro amor, de sorte que, sendo capaz de um amor infinito, o amor de si se tornou amor-próprio - buscando preencher o vazio infinito que o amor a Deus deixou, o homem passou a amar-se apenas a si próprio e todos as coisas para si próprio, ou seja, infinitamente. Vem daí, inclusive, a insatisfação perpétua de sua vontade, pois ele tenta preencher um vazio infinito por meio de coisas finitas. É, portanto, no amor-próprio que devemos buscar a fonte de todas as concupiscências (a volúpia, a curiosidade e o orgulho), pois é o $e u$, doravante equacionado ao amor-próprio, com seu desejo insaciável de tornar-se o centro de tudo, que faz com que o homem se desvie de Deus e se volte sempre, por meio das coisas, para si mesmo. Sendo assim, o orgulho pode ser considerado a principal concupiscência e chega mesmo a se confundir com o amorpróprio. Nas palavras de Sellier,

na medida mesma em que o orgulho se identifica ao culto do eu odioso, que (...) é a fonte de toda concupiscência, ele é a concupiscência a mais profunda, aquela que engendra todas as outras. O orgulho não está, então, no mesmo plano que a volúpia e a curiosidade: ele é, ao mesmo tempo, ramo, pois ele engendra comportamentos específicos como a paixão de dominar, e raiz da árvore das concupiscências (Sellier 9, p. 183).

Como já vimos, "a natureza do amor-próprio e desse $e u$ humano é não amar senão a si e não considerar senão a si” (Pascal 8, fr. 100, p. 68) e isso se explica pelo fato de que, em seu estado original, desfrutando de uma glória centrada em Deus, ele quis fazer-se o centro de si mesmo, a fonte de sua própria felicidade — desviando-se de Deus, foi por Ele abandonado e reduzido à condição semelhante àquela dos animais, sem, contudo, perder o desejo de infinitude. Desde então, ele

não poderá impedir que esse objeto que ama esteja cheio de defeitos e misérias: quer ser grande e acha-se pequeno, quer ser feliz e acha-se miserável; quer ser perfeito e acha-se cheio de imperfeições; quer ser o objeto do amor e da estima dos homens, e vê que seus defeitos só merecem deles aversão e desprezo (Pascal 8, fr. 100, p. 68).

Por que ele quer ser objeto do amor de outrem? Ora, dada sua capacidade infinita de amor - traço vazio de nosso primeiro estado —, o eu, enquanto objeto finito, não pode bastar a si próprio. Desejando ser o centro de tudo, não obstante sua 
realidade descentrada e finita, é preciso, então, que ele busque uma aparência de infinitude que seria dada pela aparente centralidade do eu em relação a todos os outros: “cada indivíduo é tudo para si mesmo, pois, ao morrer, tudo morre para ele. Daí o fato de cada um pensar ser tudo para todos" (Pascal 8, fr. 457, p. 155). Em outras palavras: “o $e u$ tem duas qualidades: é injusto em si, fazendo-se centro de tudo; é incômodo aos outros, querendo sujeitá-los: pois cada $e u$ é o inimigo e desejaria ser o tirano de todos os outros" (Pascal 8, fr. 455, p. 154). Toda a atividade do eu consiste, então, em um desejo tirânico de ser reconhecido e amado por todos os outros - e é por isso que ele deve odiar a verdade de sua condição e encobri-la tanto para si quanto para outrem. Essa aversão à verdade é inseparável do amor-próprio (Pascal 8, fr. 100, pp. 68-9), pois o desejo de ser amado não pode ser conciliado com o fato de que, na verdade, o eu é odioso e desprezível em sua tirania e injustiça. É, portanto, "falso que sejamos dignos de que os outros nos amem: é injusto que o queiramos" (Pascal 8, fr. 477, p. 158) e se, por acaso, somos amados, somos culpados por enganar aqueles que nos amam, pois "não sou o fim de coisa alguma e não tenho com que satisfazê-los" (Pascal 8, fr. 471, p. 157). De fato, o que numa pessoa poderia ser digno de amor? Sua beleza? Ela um dia envelhecerá ou poderá ter varíola e perder sua beleza... Sua inteligência, então? Pode perdê-la sem deixar de existir...

Onde está, pois, esse $e u$, se não se encontra no corpo nem na alma? E como amar o corpo ou a alma, senão por essas qualidades, que não são o que faz o $e u$, de vez que são perecíveis? Com efeito, amaríamos a substância de uma pessoa abstratamente, e algumas qualidades que nela existissem? Isso não é possível, e seria injusto. Portanto, não amamos nunca a pessoa, mas somente as qualidades (Pascal 8, fr. 323, p. 121).

Nem mesmo uma realidade substancial, tal qual a res cogitans cartesiana, pode-se conferir ao eu: ele é apenas um fluxo de qualidades transitórias sem qualquer substrato ontológico. Assim, se o eu é odioso àqueles que odeiam a sua injustiça, quer dizer, o fato de que ele deseje ser o centro de tudo, é porque eles sabem que o único objeto verdadeiramente digno de amor é Deus, pois "esse abismo infinito só pode ser preenchido por um objeto infinito e imutável, isto é, pelo próprio Deus" (Pascal 8, fr. 425, p. 141). "A verdadeira e única virtude, diz Pascal, consiste, pois, em odiar a si mesmo (porquanto somos odiosos pela concupiscência) e em buscar um ser realmente 
amável para amá-lo" (Pascal 8, fr. 485, p. 160).

\section{IV}

Enquanto apologista, Pascal nos dizia que a religião cristã cumpria o papel da única religião verdadeira, uma vez que podia explicar-nos nossa miséria, nossa grandeza e a razão de ambas. Até aí, já vimos que o cristianismo foi capaz de dar conta de sua tarefa. Entretanto, ele dizia também que a religião verdadeira deveria ensinar-nos o remédio para essa miséria e os meios de obtê-lo. Ora, dada a distância intransponível entre o finito e o infinito proveniente da queda, como é possível que o ser finito e corrompido, escravo da concupiscência, dê o salto para o infinito e possa voltar seu amor a Deus?

Quem não odeia em si o seu amor-próprio, e esse instinto que o leva a fazer-se Deus, é bem cego. Quem não vê que nada é tão oposto à justiça e à verdade? Porque é falso que mereçamos isso; e é injusto e impossível chegar a isso, uma vez que todos pedem a mesma coisa. É, pois, em uma manifesta injustiça que nascemos, da qual não podemos desfazer-nos e da qual devemos desfazer-nos (Pascal 8, fr. 492, p. 161, grifo nosso).

Aparentemente, a apologia pascaliana chega agora a uma contradição, digamos, escolar. Não podemos nos desfazer de nossa injustiça e devemos nos desfazer de nossa injustiça. Somos escravos da concupiscência e devemos amar a Deus. Curioso impasse esse a que chega Pascal. No entanto, se olharmos a questão mais de perto, veremos que é apenas aparentemente que isso constitui uma contradição. "O conhecimento de Deus sem o da própria miséria faz o orgulho. O conhecimento da própria miséria sem o de Deus faz o desespero. O conhecimento de Jesus Cristo encontra-se no meio, porque nele encontramos Deus e nossa miséria" (Pascal 8, fr. 527, p. 167). Se Pascal ressaltava a impossibilidade de uma comunicação entre as ordens da natureza e da caridade, é porque em seu projeto apologético a figura de Jesus Cristo terá o papel fundamental de mediador. Jesus é Deus e homem ao mesmo tempo e é apenas por meio dessa misteriosa união de duas naturezas nele que podemos não apenas conhecer qualquer coisa - "não só conhecemos Deus apenas por Jesus Cristo, mas ainda conhecemo-nos a nós mesmos por Jesus Cristo. Só conhecemos a vida e a morte por Jesus Cristo. Fora 
de Jesus Cristo não sabemos o que é nossa vida, nem nossa morte, nem Deus, nem nós mesmos" (Pascal 8, fr. 548, p. 170) —, mas também ter alguma possibilidade de salvação. Afinal, Jesus Cristo fez-se pecado por mim e, ao fazer recair sobre si todos os nossos flagelos, tornou-se mais abominável do que eu: "ele se curou a si mesmo e com maior razão há de curar-me” (Pascal 8, fr. 553, p. 175).

Se, naturalmente, não somos capazes de um conhecimento de Deus, o que dizer sobre isso agora que entrou em cena uma mediação? Se por conhecimento entendermos algo que nos elucide a natureza de Deus, é evidente que qualquer tentativa estará condenada ao malogro. A existência de Deus só pode ser conhecida pela fét: "não conhecemos nem a existência nem a natureza de Deus, porque não tem extensão nem limites. Mas pela fé conhecemos sua existência e pela glória conheceremos a sua natureza" (Pascal 8, fr. 233, p. 98). O Deus cristão não é o mero autor de verdades geométricas, mas um Deus de amor e consolação, que nos faz sentir nossa miséria e sua infinita misericórdia: desde então, compreende-se melhor o porquê da inutilidade de se conhecer Deus sem conhecer nossa miséria - o que nos leva ao orgulho dos deístas e de se conhecer nossa miséria sem conhecer Deus - o que nos leva ao desespero dos ateus - ; da mesma forma, conhecer a miséria e Deus sem uma razão que as coordene — Jesus Cristo - é igualmente perigoso. O conhecimento de Deus só pode ser mediado por Jesus Cristo, pois o que aparece nele "não assinala uma exclusão total, uma presença manifesta da divindade, mas a presença de um Deus que se esconde" (Pascal 8, fr. 556, p. 179). O Deus do cristianismo é, pois, não o Deus abstrato dos filósofos que redundaria, no fim das contas, em um ídolo de Deus (Pascal 8, fr. 582, p. 185) -, mas um Deus oculto que é ao mesmo tempo presença e ausência, pois, "se Deus se descobrisse continuamente aos homens, não haveria mérito em crer nele; e, se ele não se descobrisse jamais, não haveria fé" (Pascal 7, p. 267). O cristão deverá ver a clareza absoluta com muita desconfiança, pois toda a história humana se desenrola em um jogo da luz equívoca do Deus oculto - claridade e obscuridade são, portanto, inseparáveis. "Há bastante claridade para esclarecer os eleitos e bastante obscuridade para humilhálos. Há bastante obscuridade para cegar os réprobos e bastante claridade para condenálos e torná-los indesculpáveis" (Pascal 8, fr. 578, p. 184). Se não houvesse obscuridade, o homem não sentiria sua corrupção e seria tomado pela soberba dos filósofos. Simetricamente, se não houvesse claridade, os homens se perderiam no desespero e não pensariam haver um remédio possível para suas aflições. Jesus Cristo, em seu mistério, faz com que conheçamos a grandeza a partir de nossa miséria e, assim, torna-nos 
sensíveis ao sentido oculto sob o sentido manifesto, restabelecendo a possibilidade de comunicação com Deus:

A manifestação histórica da transcendência deu-se na forma do mistério, pois não é possível para a razão humana aceitar a consubstanciação da divindade e da humanidade numa só pessoa. (...) A razão reconhece a letra, o coração o espírito; por isso a razão não assimila o sentido transcendente do Fato; mas o coração pode reconhecer o advento do sentido não-histórico da história,... transpondo de um salto a distância entre o finito e o infinito na paradoxal vivência do Absoluto ausente - sentindo na ausência a forma misteriosa da presença (Silva 10, p. 161).

O que falar, no entanto, dessa comunicação com um Deus que se oculta? Qual relação pode ter o homem com um Deus que se faz presente na ausência? Deus, diz Pascal, "estabeleceu na Igreja sinais sensíveis para se fazer reconhecer pelos que sinceramente o procuram; e..., entretanto, cobriu de tal maneira esses sinais que só serão vistos por aqueles que o procuram de todo o coração" (Pascal 8, fr. 194, p. 88, grifos nossos). E, no entanto, Jesus Cristo nos diz: “'Consola-te, não me procurarias se já não me houvesses achado"' (Pascal 8, fr. 553, p. 173). Essas duas afirmações só deixarão de ser contraditórias se compreendermos o que Pascal, na esteira do jansenismo, entende por fé. "A fé, diz Pascal, é diferente da prova: uma é humana, a outra um dom de Deus. Justus ex fide vivit: dessa fé que o próprio Deus põe no coração, cuja prova é amiúde o instrumento, fides ex auditu, mas essa fé está no coração e faz que se diga credo e não scio" (Pascal 8, fr. 248, pp. 106-7). A fé é, portanto, um dom de Deus, é precisamente o que a distingue da mera superstição. É o próprio Deus que inclina o coração do cristão a crer, e isso independentemente de qualquer raciocínio ou vontade humanos. Depois do pecado original, estando os homens tão cheios de injustiça e de concupiscência, era justo que Deus os condenasse a todos, pois tornaram-se todos igualmente indignos d'Ele. No entanto, por um ato de pura misericórdia gratuita, Deus quis que alguns desses fossem salvos e, enviando Jesus Cristo para satisfazer a sua justiça, trouxe a possibilidade da redenção. Não nos enganemos, contudo: não está em poder do homem salvar-se por si próprio - dizer o contrário seria recair na soberba estóica de pensar que o homem pode igualar-se a Deus e, pior, seria tornar inúteis os sofrimentos de Cristo que nos trouxeram a possibilidade da salvação. Como dissemos, é justo que Deus condene os homens e, no entanto, é-nos misteriosa a misericórdia que 
salva alguns dentre a massa dos condenados, pois os desígnios de Deus são ocultos para nós. É através da graça que Deus nos concede que podemos ser salvos - não mais, todavia, a graça suficiente que habitava Adão, mas a eficaz, que é a única possível após o homem se ter tornado escravo da concupiscência. "A lei obriga ao que não concedia. A graça concede aquilo a que obriga" (Pascal 8, fr. 522, p. 167). Lembremos daquilo que havíamos dito mais acima: não podemos desfazer-nos de nossa injustiça, mas devemos dela desfazer-nos. A lei divina estabelece os remédios para nossa concupiscência ao nos dizer nossos deveres. Contudo, por si mesmo o homem jamais pode cumpri-los uma vez que é escravo da concupiscência. Se Adão possuía uma graça suficiente para cumprir a lei de Deus, restava-lhe, porém, aquela liberdade de indiferença que o tornava capaz de pecar. No caso do homem decaído, naturalmente inclinado ao mal, é preciso que haja uma graça eficaz, quer dizer: é preciso não só que ele realize a lei de Deus, mas também que ele queira realizá-la (Pascal 7, p. 318). A graça deve, portanto, operar uma conversão da vontade do homem pecador sem, contudo, restabelecer a indiferença da vontade adâmica. Adão podia, por seu livrearbítrio, perseverar ou não na graça. O homem decaído depende exclusivamente da operação da graça eficaz para perseverar na justiça divina: da mesma forma que Deus pode livremente conceder-nos a graça, ele pode também livremente retirá-la de nós. Diante do Deus oculto, o cristão nunca pode estar certo de que será salvo, assim como o descrente nunca pode estar certo de que não será salvo. A fé é indissociável do temor, não daquele proveniente da dúvida acerca de Deus, mas daquele que nasce da esperança no Deus em que acreditamos e que consiste no medo de perdê-lo (Pascal 8, fr. 262, p. 109).

\begin{abstract}
A conversão verdadeira consiste em aniquilar-se diante desse ser universal que tantas vezes tem sido irritado e que pode perdervos legitimamente a todo momento; em reconhecer que não se pode nada sem ele, e que nada se mereceu dele, senão a perda de sua graça. Consiste em conhecer que há uma oposição invencível entre Deus e nós, e que, sem um mediador, não pode haver comércio (Pascal 8, fr. 470, p. 157).
\end{abstract}

A graça deve operar de tal maneira no coração do homem de sorte a fazer com que ele se aniquile diante de Deus. O que significa, porém, aniquilar-se? Ora, o "se" a que reenvia o verbo aniquilar não é outra coisa que aquele "eu odioso" de que falávamos 
acima. A conversão encarrega o "ódio de si", do homem que se odeia enquanto pecador dominado pela concupiscência, de um papel central para sua realização, tanto mais central se nos lembramos de que o ódio de si é correlato do amor a Deus. "É preciso amar só a Deus e só odiar a si mesmo" (Pascal 8, fr. 476, p. 158) e essa é a única virtude que podemos ter. Esse ódio a si mesmo transforma todos os bens terrenos que nos encantavam em um nada em relação ao verdadeiro objeto de amor que é Deus - uma felicidade verdadeira não pode ser uma felicidade durável, visto que limitada à duração da vida, mas eterna. A alma agora não pode mais desfrutar tranquilamente dos bens temporais: há um "escrúpulo contínuo" que a combate nesse gozo e agora é-lhe impossível encontrar nas coisas a doçura e nelas se abandonar. "Ela considera as coisas perecíveis como perecendo e mesmo já perecidas" (Pascal 7, p. 290). Reconhecendo-se como miserável, como indigna de Deus, arrependendo-se de sua cegueira, buscando contemplar a grandeza de seu Criador, a alma "se aniquila em sua presença e, não podendo formar dela mesma uma ideia suficientemente baixa nem conceber uma suficientemente elevada desse soberano bem, faz novos esforços para se rebaixar até os últimos abismos do nada...; enfim, nessa concepção, que esgota suas forças, ela o adora em silêncio, ela se considera como sua vil e inútil criatura e, por seus respeitos reiterados, adora-o e o abençoa, e gostaria de adorá-lo e de abençoá-lo para sempre" (Pascal 7, p. 291).

Há algo, entretanto, que deve ser notado em meio às imagens patéticas deste opúsculo: a graça não pode aniquilar integralmente o $e u$, ele continua a existir no mundo que o tenta, ainda que "sem nele tomar parte e gosto" (Pascal 8, fr. 906, p. 277). A condição trágica do homem não desaparece: a graça não torna o absoluto que a alma humana almeja realizável no mundo. É por isso que Goldmann, comentando essa condição, pode falar em uma recusa paradoxal e intramundana do mundo (Goldmann 3, p. 176). A diferença é que, uma vez tocado pela graça, a relação do homem com as coisas temporais se modifica: se, em relação ao amor a Deus, todos os objetos perdem seu valor, resta que eles agora devem ser usados com vistas ao amor de Deus, o qual permanece o único fim. A misericórdia de Deus, diz Pascal, convida-nos à penitência. E é justamente o fato de haver penitência que nos indica a permanência de nossa corrupção, pois "só sofremos à proporção que o vício, que nos é natural, resiste à graça sobrenatural" (Pascal 8, fr. 498, p. 162). Ora, uma vez que não temos garantias da perseverança na graça e que nossa corrupção não é por ela inteiramente anulada, é preciso reconhecer que a penitência do cristão não acaba senão na morte: "nós sabemos 
que a vida, e a vida dos Cristãos, é um sacrifício perpétuo que só pode ser terminado pela morte" (Pascal 7, p. 276). A vida do cristão deve espelhar a vida de Cristo em seu sacrifício: "só devemos unir-nos aos seus sofrimentos" (Pascal 8, fr. 553, p. 175).

O que significa essa união do homem com Cristo em seu sofrimento? Segundo Pascal, Deus só considera os homens através do Cristo mediador, pois, neles mesmos, eles são abomináveis. Ao mesmo tempo, os homens devem, eles também, considerar a si mesmos e a outrem por essa mediação, sem o que só se encontra a infelicidade, a miséria e a injustiça. Ora, o sacrifício de Jesus serviu para santificar todos os sofrimentos e deve servir de modelo para todas as condições: "nós sabemos que o que aconteceu em Jesus Cristo deve acontecer em todos os seus membros" (Pascal 7, p. 276). Reencontramos a mesma temática nos Pensamentos:

Ser membro é só ter vida, ser e movimento pelo espírito do corpo e para o corpo. O membro separado, não vendo mais o corpo a que pertence, tem apenas um ser perecível e moribundo. (...) Ele não poderia por sua natureza amar outra coisa senão por si mesmo e para sujeitá-la a si, pois cada coisa se ama acima de tudo. Mas, amando o corpo, ama-se a si próprio, porque só tem ser nele, por ele e para ele: qui adhaeret Deo unus spiritus est. (...) A gente se ama porque é membro de Jesus Cristo. Amamos Jesus Cristo porque é o corpo de que somos membro. Tudo é um. Um está no outro, como as três pessoas (Pascal 8, fr. 483, p. 160).

Segundo Oliva (Oliva 6, pp. 120 e ss.), trata-se aqui de uma retomada da tese agostiniana do Corpo Místico de Cristo. O cristão deve unir-se ao sacrifício de Jesus Cristo na medida em que se trata de um único sacrifício que só se consumará no Juízo Final - da massa dos homens condenados Deus retira os eleitos que deverão fazer parte deste Corpo, que é onde o sacrifício pode ser enfim realizado até a conquista da redenção. Como pode o cristão unir-se ao sacrifício de Cristo? O que reaparece aqui é o tema do aniquilamento: é apenas negando-se a si mesmo, enquanto ser odioso e corrompido, que o homem pode realizar o sacrifício, até o ponto mais alto de sua negação que é a morte. É na medida em que o cristão se nega e busca o aniquilamento de seu ser que ele pode integrar o Corpo de Cristo. Essa negação é, necessariamente, dolorosa, uma vez que ela deve refletir os sofrimentos de Jesus. Nossas aflições, diz Pascal, são a matéria de um sacrifício que a graça de Deus consome e aniquila para sua 
glória, de sorte que os sacrifícios particulares, isto é, a vida de cada cristão, devem honrar e antecipar o sacrifício universal no qual a natureza inteira deve ser consumida pela potência de Jesus Cristo — “assim, nós tiraremos vantagem de nossas próprias imperfeições, posto que elas servirão de matéria a esse holocausto; pois é a finalidade dos verdadeiros Cristãos aproveitar suas próprias imperfeições, pois tudo coopera ao bem para os eleitos" (Pascal 7, p. 278). As aflições não bastam para que o homem faça parte do Corpo dos eleitos, pois todos os homens, mesmo os condenados, têm aflições. "A vida do Corpo Místico é a graça de Jesus Cristo, mas a matéria que a graça alimenta é a dor de Cristo em seus membros. Afinal, se é o amor de Deus que mantém vivo o Corpo, é preciso lembrar que Deus só ama o que temos de comum com o Filho", de sorte que a união do cristão com Cristo só pode ser feita através da dor de Cristo, pois "a dor é o que o constitui moral e ontologicamente, a dor é o verdadeiro ser do cristão" (Oliva 6, pp. 126-7).

Tocai meu coração com o arrependimento por meus pecados, porque, sem essa dor interior, os males exteriores pelos quais vós tocais meu corpo me seriam uma nova ocasião de pecado. Fazei com que eu conheça que os males do corpo não são outra coisa que a punição e a figura dos males da alma. Mas, Senhor, fazei também com que eles sejam seu remédio, fazendo-me considerar, nas dores que sinto, aquela que eu não sentia em minha alma, embora inteira doente e coberta de úlceras. Pois, Senhor, a maior dessas doenças é essa insensibilidade e essa extrema fraqueza que lhe havia retirado todo sentimento de suas próprias misérias. Fazei com que eu as sinta vivamente, e que o que me resta de vida seja uma penitência contínua para lavar as ofensas que cometi (Pascal 7, pp. 363-4).

É, portanto, apenas unindo-se ao sacrifício universal de Cristo, por meio do aniquilamento, que se torna possível alcançar a salvação. Negando-se a si mesmo, o cristão toma parte na dor de Jesus, ao ponto de essa dor converter-se em seu próprio ser. Desde então, o seu amor pode, finalmente, voltar-se a Deus, o fim único e supremo ainda que, como vimos, a realização integral do aniquilamento do eu só se consume na morte, de sorte que a vida do cristão deve caracterizar-se pela penitência contínua. Se a condição humana, paradoxal e angustiante, é essencialmente a condição de um ser decaído, na qual as marcas de sua condição anterior ainda são sensíveis, como feridas que nunca se cicatrizam, inscrevendo-lhe na alma a exigência de um absoluto 
irrealizável na ordem do mundo, então o aniquilamento se torna ineludível para a salvação, na medida em que há uma rígida correlação entre o ódio a si e o amor a Deus. Para o cristão, não há qualquer possibilidade moral senão o sacrifício: a dor e a graça são, enfim, apenas o avesso e o direito de uma mesma coisa.

\section{REFERÊNCIAS BIBLIOGRÁFICAS:}

1. BÉNICHOU, P. Morales du grand siècle. Paris: Gallimard, 1948.

2. CHEVALLEY, C. Pascal: contingence et probabilités. Paris: PUF, 1995.

3. GOLDMANN, L. Le Dieu caché. Paris: Gallimard, 1959.

4. LEBRUN, G. Blaise Pascal: voltas, desvios e reviravoltas. São Paulo: Brasiliense, 1983.

5. MERLEAU-PONTY, M. Sens et non-sens. Paris: Gallimard, 1996.

6. OLIVA, L.-C. As marcas do sacrifício: um estudo sobre a possibilidade da história em Pascal. São Paulo: Humanitas, 2004.

7. PASCAL, B. Euvres complètes. Paris: Seuil, 1963.

8._._. Pensamentos in Os Pensadores, XVI. São Paulo: Abril Cultural, 1973.

9. SELLIER, P. Pascal et Saint-Augustin. Paris: Armand Colin, 1970.

10. SILVA, F. L. "Pascal: história e transcendência" in Stein, E.; Boni, L. (Org.) Dialética e liberdade. Petrópolis: Vozes, 1993.

\section{THE PAIN AND THE GRACE: THE ISSUE OF ANNIHILATION IN PASCAL}

Abstract: In this text, we intend to analyze how the issue of annihilation appears in the philosophy of Blaise Pascal as the moral duty of the Christian. Once that the idea of original sin occupies a central place in this philosophy, it's from the consideration of the fallen human condition and the advent of the mediator Jesus Christ in history, restoring the possibility of salvation, that we'll find the elements to understand the salvific character that the sacrifice takes within Pascal's moral doctrine.

Keywords: Pascal, original sin, annihilation, grace, Jesus Christ. 


\section{NOTAS:}

${ }^{1}$ Com isso não se quer dizer que não haja certeza dos princípios. Simplesmente, a certeza que obtemos pelos sentimentos do coração não é discursiva: "Conhecemos a verdade não só pela razão mas também pelo coração; é desta última maneira que conhecemos os princípios, e é em vão que o raciocínio, que deles não participa, tenta combatê-los" (Pascal 8, fr. 282, p. 111). Falamos em "consenso linguístico" apenas para indicar a arbitrariedade da ligação entre o nome e a coisa.

${ }^{2} \mathrm{O}$ que não significa uma exclusão absoluta da razão. É preciso lembrar que a análise pascaliana da situação humana nos conduz não a um ponto fixo ontológico, como em Descartes, mas a um ponto fixo hermenêutico: Jesus Cristo é o ponto fixo na medida em que ele pode centrar uma realidade descentrada, dar sentido à existência, ao ser do homem e à história, pois todas as contradições podem ser harmonizadas nele, de sorte que ele aparece como a razão de todos os efeitos contraditórios. A razão, impotente para compreendê-lo, pode apenas notar seu poder interpretativo e, assim, submeter-se ao que a ultrapassa: mesmo para o cristão, a razão continua operando à luz da fé. É o que diz a sabedoria divina: "Não quero que me submetais vossa crença sem razão e não pretendo assujeitar-vos com tirania. Não pretendo tampouco tudo justificar-vos. E, para acordar essas contrariedades, entendo mostrar-vos claramente, com provas convincentes, marcas divinas em mim, marcas que vos convençam do que sou e me confiram autoridade mediante maravilhas e provas que não possais recusar; e que, em seguida, acrediteis sem [hesitar] nas coisas que vos ensino, quando não encontrardes outra razão de recusá-las, exceto que não podeis saber por vós mesmos se existem ou não" (Pascal 8, fr. 430, p. 145). 